\title{
Brexit and trade ties between Europe and Commonwealth states in sub-Saharan Africa: Opportunities for pro-poor growth or a further entrenchment of North-South inequalities?
}

\begin{abstract}
Brexit will of course have major implications for trade between Commonwealth African nations and the European continent. In the short term, the European Commission's Economic Partnership Agreements (EPAs) with regional groups such as the East African Community will be complicated by the UK's decision to leave the European project. Moreover, there are longer term consequences to be considered, not least the role which the UK - as an independent trade actor - will adopt in its trade relations with Commonwealth African countries. This article examines the impact of Brexit for Commonwealth African nations' trade with Europe (including the UK). It particularly points to several potential pitfalls arising from the Brexit referendum vis-à-vis African development.
\end{abstract}

\section{Keywords}

Brexit, Africa, trade, political economy, UK, European Union, EPA

\section{Correspondence Address}

Dr Mark Langan

Lecturer in International Politics

Department of Politics and International Relations

Attenborough Tower

University of Leicester

Leicester

LE1 7RH 


\section{INTRODUCTION}

The 'Brexit' decision of the United Kingdom (UK) electorate to leave the European Union (EU) will of course have major implications for Commonwealth states in terms of their trade with European partners. This is particularly the case for Commonwealth countries in sub-Saharan Africa that have recently been engaged in prolonged negotiations for Economic Partnership Agreements (EPAs) with the European Commission. Since the launch of the EPA agenda under the Cotonou Agreement (20002020) signed between the EU and the African, Caribbean and Pacific (ACP) countries, African negotiators (especially) have been concerned about the impact of 'reciprocal' free trade with the EU for fledgling manufacturing industry and agricultural production (Langan 2015; Nunn and Price 2004; Hurt 2003). Nonetheless, there had been recent progress in the bilateral negotiations. The Heads of Government of the Economic Community of West African States (ECOWAS), for instance, agreed in principle in July 2014 to a full regional EPA with the EU member states (European Commission 2014). Meanwhile, in the same year, the East African Community (EAC) provisionally initialled a region-wide EPA with the European Commission. The full ratification and implementation of these EPAs - to the chagrin of Directorate General (DG) trade in Brussels - now stands in jeopardy due to the complications of Britain's Brexit decision. Notably, in the East African scenario, Uganda and Tanzania are now questioning whether they should go ahead and fully sign the EPA by the $30^{\text {th }}$ September 2016 deadline. This is despite the decision of their EAC partners - Rwanda and Kenya - to move forward and commit themselves to the trade agreement, as per their governments' signatures in Brussels on $1^{\text {st }}$ September 2016 (The Financial Times 2016).

Beyond the immediate complications of the EPA negotiations, however, the Brexit vote now augurs a new trading scenario in which the UK will (according to all government statements thus far) negotiate as an autonomous and independent economic player with other states in the global arena. Brexit therefore means that the UK must devise its own trade policy agenda, not least in terms of its relationship with the Commonwealth countries in sub-Saharan Africa. During the Brexit referendum, many leading Brexiteers in fact cited what they deemed the EU's unfair trade stance towards poorer Commonwealth African states as a moral reason for UK voters to reject the European supranational enterprise (Lilley 2016a). The UK - freed from the control of the Brussels bureaucracy - would be able to devise its own progressive trade approach to African developing countries. Britain could thereby pay greater heed to the historical linkages (and moral obligations) of the Commonwealth. The apparent decision of the new Theresa May government in the UK to press ahead with the invocation of Article 50 now creates the scenario in which Britain must resolve itself to the material construction of this new trading relationship. In the case of Commonwealth states in Africa, this means that there are potential opportunities - as well as dangers - of a new, autonomous UK trading partner. Moreover, the ability of the UK to make alternative decisions to DG Trade within the European Commission in Brussels - may lead to certain pressures for EU officials themselves. African countries, if offered a 'fairer' trading arrangement from the UK, may grow increasingly impatient with EU trade priorities, not least in terms of EU protectionism embodied by the Common Agricultural Policy (CAP) (Lilley 2016b).

In this context, this article explores the potential consequences of Brexit for Commonwealth countries in sub-Saharan Africa. It does this both in the context of EU trade negotiations (and policies) in the region - and in terms of the likely stance adopted by the UK as an independent trade actor. This draws attention to opportunities for enhanced African agency in negotiations with European 'partners'. It also underscores areas in which existing inequalities (and forms of exploitation) might in fact be entrenched by the various repercussions of Brexit upon Commonwealth Africa's trade and economic ties with the European continent (including the British Isles). The article is structured as 
follows. First, it provides historical context to Commonwealth Africa's trade with Europe. This addresses the EPA negotiations with the European Commission since the onset of the Cotonou Agreement in 2000. Second, the article explores the impact of the Brexit decision for the EU's ongoing trade and economic relationship with Commonwealth African countries as part of the wider African, Caribbean and Pacific (ACP) bloc. This considers recent fractures within the EPA negotiations, particularly in the case of Commonwealth members of the EAC. It also points to possible longer-term consequences, for instance relating to trade policy reform in the absence of UK influence within Brussels. Third, the article examines the possible trading scenarios between an independent UK trade actor and Commonwealth Africa. This draws attention not only to debates about tariff lines and free trade - but, crucially, to wider trade matters in relation to foreign direct investment (FDI) from UK sources. Finally, the conclusion reiterates potential dangers augured by the Brexit vote for poverty reduction and development in Commonwealth Africa.

\section{COMMONWEALTH AFRICA AND TRADE WITH EUROPE: RECIPROCAL TRADE UNDER COTONOU}

Before examining the impact of the Brexit referendum, it is first necessary to provide context in terms of the recent history of Commonwealth African countries' trade linkages with Europe. Notably, upon the UK's accession to the European Economic Community (EEC) in 1973, Commonwealth states in Africa soon became 'Associated' with the European project in Brussels (Galtung 1973; Brown 2002). Following on from the original Association of the EEC with Francophone African colonies in 1957, the Commonwealth African states joined with Francophone counterparts to sign the Lome Conventions in 1975. As part of the newly formed ACP grouping, the Commonwealth African nations soon enjoyed 'non-reciprocal' trade access to the markets of the EEC member states. This meant that they received preferential low-tariff access into EEC markets for certain commodity lines as compared to other competitor states, for instance those of Latin America or East Asia. This non-reciprocity arrangement also meant that these African countries were not obliged (initially) to dismantle their own tariffs levied upon imports originating from European states. This apparent 'spirit of Lome' sought to give the ACP countries access to the European market while allowing them the policy space to develop fledgling enterprise without the dangers of import-flooding from cheaper European commodities. In reality, however, the complications of structural adjustment programmes (SAPs) supported by the European Commission in the 1980s and 1990s - combined to European protectionism under the CAP - did much to whittle away the developmental promise of the first Lome accord as signed in 1975 (Mailafia 1997; Farrell 2005).

More recently, the Commonwealth African countries updated their Association arrangements with the European Commission under the Cotonou Partnership Agreement signed in 2000. Crucially, the Cotonou Agreement underlined the need for 'reciprocal' trade between the EU and the ACP bloc. This (ostensibly) owed to World Trade Organisation (WTO) rulings on the matter of preferential trade practised during the Lome years. Most famously, the so-called 'banana wars' undermined the preferential status awarded to ACP states' agricultural producers as compared to their counterparts in other developing regions - notably in this case, Latin American countries host to the large US multinational, Chiquita (Josling 2003). The Cotonou Agreement, therefore, sought to usher in reciprocal trade between the EU and sub-regions of the ACP group (via the EPAs) as per WTO rulings. As mentioned in the introduction, however, slow progress has been made on the EPAs - with only recent success in Eastern and Western Africa as part of decisions taken by Heads of Government in 2014. Somewhat paradoxically in light of Brexit, this slow progress was despite the energetic leadership of Peter Mandelson, the UK/EU Commissioner who headed DG Trade in the mid-2000s. Mandelson articulated a somewhat aggressive free trade position with regards to the conclusion of the EPAs with African countries, in particular. Perhaps most famously, he was accused of shouting in 
'neo-colonial' style at African dignitaries during one negotiating session (Langan 2011). He also referred, unflatteringly, to Nigeria as being the 'elephant in the road' to the success of his EPA endeavours (Leadership 2007).

Importantly, the underlying reason for the slow progress of the EPA negotiations has been the concern exhibited by African and European politicians, civil society groups, and trade unions about the regressive consequences of these free trade vehicles for pro-poor development in sub-Saharan Africa. In Commonwealth states - such as Nigeria, Kenya, Uganda and Ghana - this concern has been particularly vocal, with progressive alliances being formed between domestic civil society groups and European counterparts (Trommer 2014). For instance, the National Association of Nigerian Traders has played a pivotal role in drawing attention to the likely negative impact of an ECOWAS EPA for nascent industry in sectors including tomato agro-processing, textiles, and paper manufacturing (Muhammad and Ogwu 2014). Meanwhile, Seatini Uganda (2015) has mobilised local student movements against EPA ratification within a domestic lobbying effort aimed at the government of Yoweri Museveni. Together with European civil society under the Stop EPA campaign, such African activists have had an impact both upon public opinion within Commonwealth Africa (and Europe) as well as upon domestic trade ministries in capitals such as Kampala and Abuja. Indeed, their success was perhaps best exemplified by the exasperation of Peter Mandelson (while DG Trade Commissioner) who accused civil society groups as being responsible for the stalling of the conclusion of free trade talks (Del Felice 2012). It is into this already complicated negotiating environment that the Brexit referendum has fallen, much to the chagrin of the current EU trade officials in Brussels.

\section{BREXIT AND THE EPAS: WHERE NOW FOR DG TRADE, AND FOR COMMONWEALTH AFRICA?}

From the perspective of DG Trade officials in Brussels, the Brexit decision threatens to reopen the "Pandora's box" of EPA negotiations just as success appeared to have been attained in the pivotal Eastern and Western African regions. Anglophone Commonwealth nations have particularly raised the question of whether they should proceed with the full signing and ratification of an EPA with the European Commission if the UK (following Brexit) is no longer a party to this free trade framework. The government of Tanzania, for example, explained that it would no longer sign the EPA by the deadline of $30^{\text {th }}$ September 2016 due to the 'uncertainty in the EU after the exist of UK'. The government further explained that it sought to 'protect the economic interests of our countries by empowering the manufacturing industries' and that the current EPA framework 'may adversely affect our existing industries'. In addition, the Ugandan President, Yoweri Museveni, also cited Brexit as the reason for his country's decision to likewise retreat from full signing of an EAC EPA with the European Commission (The Financial Times 2016).

Interestingly, in this East African context, the best case scenario for EU trade negotiators would appear to be that African officials in reluctant nations such as Tanzania and Uganda are in fact merely seeking to leverage Brexit for greater concessions from Brussels (rather than to bring about a wholescale rejection of free trade deals altogether). In particular, there is opinion that these Commonwealth EAC nations are strategically seeking better terms with the European Commission than had previously been agreed prior to the Brexit vote. Specifically, leaders in Dar es Salaam and Kampala are looking to the recently concluded negotiations between the EU and the Southern African Development Community (SADC) with a certain envy (ibid). This regional SADC-EU EPA appears to have brought in some progressive elements compared to past EU free trade deals (for instance with Caribbean nations), especially in terms of more flexible rules of origin (ROOs) pertaining to value addition within Southern African production chains (Logan 2016). SADC negotiators also managed to extract a concession from the European Commission about the prohibition of agricultural subsidies within the EU member states themselves (as pertaining to EU agricultural exports into sub-Saharan 
Africa). It would seem, therefore, that EAC negotiators are using the 'opportunity' of Brexit to press for similar terms enjoyed by their SADC counterparts in trade relations with the EU member states. Again, this interpretation would appear to be the least-worst-option for Brussels officials. Indeed, the alternative would be the wholescale rejection of the EPA process (on the grounds of the damage caused by premature free trade to nascent industry and agro-processing in Eastern Africa, as expressed by civil society campaigners such as those within Seatini Uganda).

It is perhaps important to note here that Commonwealth African nations have a particular case to make in terms of the impact of Brexit upon the EPA packages that they are currently negotiating. Commonwealth African states - due to the colonial heritage and the continuing (asymmetric) patterns of North-South trade - have historically depended upon trade links with the UK, as compared with other EU member states such as Germany or France. The likely prospect of the UK withdrawing from the EPA enterprise therefore has a greater impact upon Anglophone former British colonies (that is, Commonwealth Africa) than upon those African nations once colonised by France, Belgium and other European powers.

For example, Kenya (as a former British colony) has raised major concerns about the impact of Brexit for its agricultural and horticultural producers in terms of their ties to essential British consumers, particularly vis-à-vis the lucrative cut-flower industry. The withdrawal of the UK from the EPA process creates major uncertainty as to the tariff basis upon which Kenyan cut-flower farms will be able to access British consumers via major chains such as Tesco and Sainsburys. Meanwhile, the stalling of the regional EAC EPA negotiations (due to the concerns raised by Tanzania and Uganda) threatens to damage the Kenyan flower sector in the short to medium term. The threat of Kenya defaulting to the Generalised System of Preferences (GSP) if the EAC EPA is not fully signed would mean higher tariffs being imposed upon Kenyan flowers when entering into the EU (including the UK, for the time being). The Kenyan Flower Council (KFC) has estimated that this could cost the industry around 4 billion Kenyan shillings per month - equivalent to $f 29.7$ million per month in UK sterling (Kuo and Kazeem 2016). Nevertheless, despite the difficulties faced by sectors such as Kenya's cut-flower sector, it also relevant to underscore that Africa's overall dependence on the UK market has in fact declined (relative to other European nations) since the onset of the Cotonou Agreement. Phosa (2016) explains that Africa exported goods worth $\$ 13.5$ billion to the UK in 2015, down 54\% from 2013 (\$28.7 billion). Imports from Britain into Africa, meanwhile 'have fallen 31 percent to \$11.6 billion in 2015 from $\$ 16.8$ billion in 2013'. This trend might in fact cushion - although not eliminate - the negative repercussions of Brexit for Commonwealth Africa.

The Brexit decision has therefore clearly opened up new avenues for African negotiators to challenge the European Commission on the detail of the regional EPAs, if not to reject the EPAs in their entirety. This will - as already seen in the case of the EAC divisions - likely complicate the full signing and material implementation of these free trade deals in the short to medium term. With regards to the longer term implication of Brexit for EU-Africa trade relations, however, there are other issues which need to be highlighted. Namely, that the withdrawal of the UK from decision-making processes in the European Council and the European Commission, will have a tangible impact on the trade policy direction of the EU supranational project as a whole. Notably, the UK and its representatives had gained a reputation within Brussels as a leading force among 'Northern' states committed to the principle of free trade and global market integration (Fasan 2016). These free market 'globalists' had played an important role in the conclusion of the Cotonou Agreement itself, which whittled away preferences given to the ACP bloc compared to other developing regions (Josling 2003).

Additionally, the UK alongside other 'Northern' states (including the Netherlands and Germany) had been viewed as an important voice for the reform of the controversial CAP and its 
agricultural protectionism (EurActiv 2010; Fasan 2016). The UK's role within Brussels to reform the CAP had been largely welcomed by African ministries on the basis that this instrument distorts Africa's own agricultural production (Fasan 2016). Indeed, the CAP and the interests of French farmers (in particular) has long underpinned the European Commission's levying of higher tariffs upon processed agricultural goods emanating from Africa. This compares to lower tariffs levied upon raw materials such as cocoa beans or unprocessed tomatoes. Moreover, the CAP has been seen as responsible for various episodes of agricultural commodity 'dumping' of European produce into African markets undercutting the livelihoods of African farmers (Oxfam 2002). The absence, therefore, of UK ministers in the European Council, of UK Members of the European Parliament, and of UK Commissioners within the DGs will have a detrimental impact on efforts to meaningfully reform the CAP. This clearly has a negative connotation for African economies, including those Commonwealth nations such as Uganda and Tanzania who are already reticent about the 'development' impact of EU trade policy agendas. Brexit - in the ways described above - will thus complicate already complex trade ties between Commonwealth states in sub-Saharan Africa and the members of the EU.

\section{BREXIT AND THE UK AS AN INDEPENDENT TRADE ACTOR IN SUB-SAHARAN AFRICA}

Brexit will of course also substantially impact Commonwealth nations in sub-Saharan Africa in terms of the role of the UK itself as an autonomous and independent trade partner. The UK government has made clear that trade policy will no longer be collectively made in Brussels alongside the (remaining) EU member states. Instead a new Department for International Trade has been created under Dr Liam Fox. This leaves open various scenarios in terms of the actions of the UK in its trading relationship with Commonwealth developing countries, not least those of sub-Saharan Africa. As mentioned, the Brexit campaign itself often invoked a British duty to offer African nations (especially) a fairer deal than they had heretofore obtained from the European Commission (Lilley 2016a). Influential Brexiteers, including Peter Lilley MP and Boris Johnson (now the foreign secretary), openly spoke of the need for an independent British trade competency in order to deliver poverty reduction and economic growth in Commonwealth African nations.

This ostensible progressive UK trade policy option has been outlined most clearly by the aforementioned Peter Lilley (2016b) in a post-Brexit discussion of the future of British interactions with Commonwealth developing countries. Lilley makes clear that the UK ought to provide nonreciprocal access to these developing nations. This would replicate earlier existing arrangements as occurred under the ACP-EEC Lome Conventions from 1975 to 2000. It would also somewhat mirror the EU's own existing scheme even within the era of the Cotonou Agreement - namely, the Everything But Arms (EBA) arrangement. Crucially, however, this EBA scheme is only offered by the EU to the very least developed nations, such as Uganda and Somalia (and not to more prosperous developing countries such as Kenya or Nigeria). Lilley (2016b) also documents the need for the UK government to dismantle non-tariff barriers (NTBs) currently placed upon African produce entering into European markets. These include stringent hygiene and phytosanitary requirements as placed, for instance, upon cut-flowers emanating from Kenya (as well as other horticultural producers such as in neighbouring Uganda and Tanzania). Perhaps most interestingly, Lilley (2016b) has also advocated for the UK to refrain from imposition of protective subsidises upon its own farmers and agriculturalists. In contrast to the EU's CAP regime, Lilley states that the UK should abide by the norms of free trade and (therefore) should not seek to artificially support British producers at the expense of African competition. If implemented, this would mark a radical shift in trade between the UK and Commonwealth nations in sub-Saharan Africa. In theory, it would give much better export opportunities for African producers in sectors including beef, poultry and (processed) dairy produce. 
Importantly, other advocates of a pro-development and pro-Africa UK trade policy point to the need for British trade officials to refrain from granting zero-duty access to other regions. Notably, there is discussion here about the Most Favoured Nation (MFN) tariff rates that the UK should agree within its trading partners within WTO fora (Laurent cited in Royal African Society 2016). Indeed, if the UK were to agree low MFN tariffs that gave (near) zero-duty access to Latin American and Asian producers, then any benefits possibly offered by a low tariff deal with Commonwealth African nations would effectively be nullified. There is thus discussion that UK trade policy ought to give a relative advantage - or preference - to exporters from poorer African nations as compared to their competitors in other regions (such as Latin America). If the UK were to offer fully free access to British consumers to all potential trading partners, then African agriculturalists and manufacturers would not be able to compete alongside other regions that enjoy greater economic resources. Interestingly, this issue of preference erosion has often been cited as one of the main reasons for the relatively disappointing performance of African economies during the Lome Conventions with the EEC (Brown 2002; Hurt 2003). UK policy should therefore learn the lessons of past preference erosion and ensure that its own trade orientation affords genuine opportunities for African entrepreneurs.

However, there are grounds upon which to doubt whether the UK government will have the will or the capacity to deliver such a progressive trade policy vis-à-vis African countries, including Commonwealth nations whose wellbeing was (ostensibly) a central moral concern of leading Brexit advocates. In particular, there are grounds to doubt whether the UK would refrain from domestic protections upon its own agricultural producers - and corporate agribusiness. There is also doubt as to whether the UK government (at least as currently comprised by Conservative Party members) would dismantle tariffs upon value-added, processed good originating from sub-Saharan Africa. Indeed, the UK government has to date been a leading supporter of agribusiness interests - notably in terms of its very recent championing of the New Alliance for Food Security and Nutrition (NAFSN) (ActionAid 2014). Leading UK Conservative Party politicians (including the current trade minister, $\mathrm{Dr}$ Liam Fox) have hailed the NAFSN as an opportunity for enhanced foreign direct investment (FDI) of major companies including Diageo, Unilever, SABMiller, and Syngenta into African agricultural production (Fox 2016). Moreover, the UK government as one of the leading states within this multidonor initiative, has taken the lead role in the implementation of the NAFSN in agreements with Commonwealth nations such as Ghana (ActionAid 2014). This NAFSN plan will ostensibly enhance FDI into such African states by improving private property rights, improving the business investment climate, and by identifying unproductive land tracts (or agricultural corridors) into which investment can be placed. Crucially, however, the NAFSN has been widely condemned (including by a recent European Parliament enquiry) for essentially facilitating 'land-grabbing' exercises in Commonwealth Africa, and beyond (The Guardian 2016). Local subsistence farmers have been forcibly removed including, at times, through use of rape as a tool of intimidation - in order to make way for FDI from the major NAFSN corporate players (ActionAid 2014).

In the context of Britain's fulsome support for the NAFSN endeavour (including, as mentioned, enthusiastic support from the current UK trade minister, Dr Liam Fox) it is questionable whether UK policy should follow a progressive, pro-poor stance that prioritises the needs of African producers at the (de facto) expense of British agriculturalists and agri-business. Certainly in terms of the current ideological configuration of Her Majesty's government, it would seem unlikely that the British trade ministry would seek such a radical departure from heretofore policy directions. Moreover, as mentioned, the UK government even in the years of Tony Blair and Labour Party ascendancy fully supported a free market 'EPA' agenda despite warnings from civil society groups and African governments about its likely impact upon poorer communities. Labour Party officials, such as Peter Mandelson, played a leading role in the negotiation of reciprocal free trade deals in sub-Saharan 
Africa. It would therefore seem unlikely that UK politicians of the Centre Left and Centre Right would bring about the policy shift that idealistic Brexiteers such as Peter Lilley would like to witness. Meanwhile, the current Labour Party opposition in the UK Parliament - presently led by Jeremy Corbyn, an opponent of Blairite Centrism - seems unable to offer a meaningful electoral challenge to Conservative Party ascendancy. A progressive policy volte-face within British trade officialdom thus appears most unlikely. In fact a progressive trade policy within the British Isles would seemingly be most likely in the case of Scottish independence, given the policy direction of the Scottish National Party (SNP) within the Holyrood parliament in Edinburgh. The ability or willingness of Westminster politicians in England to deliver a pro-poor direction in trade with Commonwealth Africa is highly questionable.

Perhaps most worryingly, however, there is also the possibility that British forms of FDI into sub-Saharan African states (including Commonwealth nations) may become more regressive in the absence of pan-European civil society oversight. As Siles-Brugge (2016) argues in the context of the Transatlantic Trade and Investment Partnership (TTIP), the most regressive aspects of trade and investment policy have been held to public account by pan-European civil society campaigning. This is also the case in terms of the role of Development Finance Institutions (DFIs) such as the European Investment Bank (EIB) or in the UK context, the Commonwealth Development Corporation (now rebranded simply as the CDC) (Bracking 2009). Pan-European civil society efforts have drawn attention to the ways in which DFIs have supported extractive industries based upon exploitative workplace practices in Commonwealth African nations such as Zambia and Kenya (CounterBalance 2010). They have also pointed to the ways in which these DFIs have supported companies that exploit tax havens to avoid paying full revenues to host Commonwealth African governments (ibid).

Moreover, it is civil society action on a pan-European level that has drawn public attention to the aforementioned NAFSN and 'land-grab' episodes (ActionAid 2014). It is the actions of the European Parliament itself that have particularly drawn attention to regressive instances of labour (and human) rights abuses via NAFSN policy platforms. There is an emerging danger, therefore, that UK DFIs (namely, the CDC) as well as UK government/corporate action as part of 'development' schemes such as the NAFSN might receive less critical attention following Brexit. There is in fact a real need for wider European civil society groups to liaise with their undermanned UK counterparts to hold the British government and its corporate sponsors to full account in terms of their post-Brexit interventions in Commonwealth African economies.

\section{CONCLUDING REMARKS}

Frome the above discussion it would appear that Brexit, on balance, offers fewer opportunities for Commonwealth African nations' trade position vis-à-vis European 'partners' while opening up many potential hazards. Despite the short-term advantages of Brexit as a leverage device in EPA negotiations with the European Commission, nevertheless, the long-term potential for a more progressive trade relationship to arise from Westminster corridors remains somewhat remote. Despite the optimism of observers such as Peter Lilley (2016a; 2016b) about the potential of the UK government to usher in new policy directions, it would appear that the British state will continue to support its corporate stakeholders even where such action may impinge upon African livelihoods and labour/human rights. Worryingly, the current UK trade minister is a forceful advocate of the NAFSN, an initiative strongly condemned by a recent European Parliament enquiry into land-grabbing within 'agricultural corridors' in sub-Saharan Africa (including in Commonwealth countries such as Ghana and Kenya).

Meanwhile, the role of the UK as a 'spoiler' in relation to the CAP (much to the historical chagrin of French, Italian and Spanish politicians) will no longer be present within the European 
Commission and European Council. The apparent advantages of the UK as a purist free trade advocate vis-à-vis the CAP will no longer be available from the standpoint of African governments. Indeed, certain African governments have already expressed their regret about the outcome of the Brexit referendum on the basis that the British will no longer have influence over the policy direction of the CAP within the EU project. On a final note, meanwhile, it is perhaps also necessary to reflect upon how the decision of the UK public (or at least those within England and Wales) to exit the EU may have a negative impact on similar regional projects within sub-Saharan Africa. The aforementioned ECOWAS group and the EAC bloc are themselves examples of regional co-operation in which neighbouring countries agree a common economic agenda and, at times, forfeit individual short-term advantages for the greater good. The decision of British voters (or more accurately, the English and Welsh electorates) to exit the EU augurs ill for the future success of other regional projects. In fact it may legitimate - and inspire - forms of banal nationalism within African countries to the detriment of the unity of regional groupings such as the EAC and ECOWAS.

\section{REFERENCES}

ACTION AID (2014) The Great Land Heist, Action Aid: Johannesburg

BRACKING, S. (2009) Money and Power: Great Predators in the Political Economy of Development, London: Pluto Press

BROWN, W. (2002) The European Union and Africa: The Restructuring of North-South Relations, London: I.B. Tauris \& Co. Ltd.,

COUNTER BALANCE (2010) The Mopani Copper Mine, Zambia: How European Development Money Fed a Mining Scandal, Brussels: Counter Balance

DEL FELICE, C. (2012) Power in discursive practices: the case of the Stop EPAs campaign, European Journal of International Relations, 20(1), pp. 145-167

EURACTIV (2010) UK ministers see EU allies in CAP reform debate, EurActiv, $18^{\text {th }}$ May 2010

FARRELL, M. (2005) A triumph of realism over idealism? Cooperation between the European Union and Africa, European Integration, 27(3), pp.263-283

FASAN, O. (2016) Brexit: why Africa will lose a voice in Brussels but gain the best of both worlds, International Growth Centre, $18^{\text {th }}$ July 2016

THE FINANCIAL TIMES (2016) Kenya feels Brexit effect as UK vote threatens Africa trade deal, The Financial Times, $28^{\text {th }}$ July 2016

GALTUNG, J. (1973) The European Community: A Superpower in the Making, London: Allen \& Unwin

THE GUARDIAN (2016) European Parliament slams G7 food project in Africa, The Guardian, $8^{\text {th }}$ June 2016

HURT, S. (2003) Co-operation and coercion? The Cotonou Agreement between the European Union and the ACP states and the end of the Lomé Convention, Third World Quarterly, 24(1), pp.161-176 
Josling, T. (2003) Banana Wars the Anatomy of a Trade Dispute, Oxon: CABI

KUO, L. AND KAZEEM, Y. (2016) Brexit will be terrible for Africa's largest economies, Quartz Africa, $24^{\text {th }}$ June 2016

LANGAN, M. (2011) Private sector development as poverty and strategic discourse: PSD in the political economy of EU-Africa trade relations, Journal of Modern African Studies, 49:1, pp. 83-113

LANGAN, M. (2015) Budget support and Africa-European Union relations: free market reform and neocolonialism? European Journal of International Relations 21(11), pp. 101-121

LEADERSHIP (2007) Why Nigeria is a sitting 'elephant', Leadership (Abuja), 18 ${ }^{\text {th }}$ November 2007

LILLEY, P. (2016a) The truth about Britain's trade outside the European Union, The Telegraph, $26^{\text {th }}$ May 2016

LILLEY, P. (2016b) Post-Brexit free trade helps the world's poorest, Comment Central, $4^{\text {th }}$ July 2016

LOGAN, S. (2016) Brexit may change the thrust of African trade with the EU and Britain, Moneyweb, $31^{\text {st }}$ August 2016

MAILAFIA, O. (1997) Europe and Economic Reform in Africa: Structural Adjustment and Economic Diplomacy, London: Routledge

MUHAMMAD, H. AND OGWU, S. (2014) Nigeria: experts warn of collapse of Nigeria's manufacturing sector over EPA, Daily Trust, $28^{\text {th }}$ October 2014

NUNN, A. AND PRICE, S. (2004) Managing development: EU and African relations through the evolution of the Lome' and Cotonou Agreements, Historical Materialism, 12(4), pp. 203-230

OXFAM (2002) Stop the dumping! How EU agricultural subsidies are damaging livelihoods in the developing world, Oxfam Briefing Paper, No. 31

PHOSA, M. (2016) Africa will rise from the Brexit ashes, Africanindy, $5^{\text {th }}$ August 2016

ROYAL AFRICAN SOCIETY (2016) Post-Brexit Africa-UK trade and investment agreements, Royal African Society Blog - RAS News, $28^{\text {th }}$ July 2016

SEATINI UGANDA (2015) Student's involvement in investment negotiations is key, Seatini Uganda, 2015. Available at: http://www.seatiniuganda.org/students-involvement-in-investment-negotiationsis-key/ Accessed $3^{\text {rd }}$ September 2016

SILES-BRUGGE, G. (2016) Taking control? The trade policy consequences of Brexit, SPERI Comment, $30^{\text {th }}$ June 2016

TROMMER, S. (2014) Transformations in Trade Politics: Participatory Trade Politics in West Africa, London: Routledge 